\title{
Liver regeneration with I-glutamine supplemented diet: experimental study in rats
}

\section{Avaliação da regeneração hepática com dieta suplementada com l-glutamina: estudo experimental em ratos}

\author{
Cibelle Ribeiro Magalhäes ${ }^{1}$; Osvaldo Malafaia, ECBC-PR'; Orlando Jorge Martins Torres, TCBC-Ma²; luciane Bugmann
}

Moreira'; Silvia Carmen da Silva Gonçalves Tefil'; Matheus da Rocha Pinherio ${ }^{3}$; Bruna Ayumi Harada ${ }^{3}$

\section{A}

\begin{abstract}
Objective: To assess liver regeneration in rats after $60 \%$ hepatectomy with and without supplementation of L-glutamine through liver weight changes, laboratory parameters and histological study. Methods: 36 male rats were divided into two groups: glutamine group and control group. Each group was subdivided into three subgroups, with death in $24 \mathrm{~h}, 72 \mathrm{~h}$ and seven days. The glutamine group received water and standard diet supplemented with L-glutamine, and the control recieved $0.9 \%$ saline. In all subgroups analysis of liver regeneration was made by the Kwon formula, study of liver function (AST, ALT, GGT, total bilirubin, indirect and indirect bilirubin and albumin) and analysis of cell mitosis by hematoxylin-eosin. Results: In both groups there was liver regeneration by weight gain. Gamma-GT increased significantly in the control group $(p<0.05)$; albumin increased in the glutamine group. The other indicators of liver function showed no significant differences. Histological analysis at $72 \mathrm{~h}$ showed a higher number of mitoses in the glutamine group, with no differences in other subgroups. Conclusion: Diet supplementation with $L$ glutamine is beneficial for liver regeneration.
\end{abstract}

Key words: Evaluation. Hepatectomy. Liver regeneration. Diet. Glutamine.

\section{INTRODUCTION}

he liver is considered one of the most complex organs in the human body. It tends to maintain the same mass throughout life, for that requiring regeneration'.

The good results in extended hepatectomies are constant thanks to more improved surgical techniques and perioperative management, as well as the regeneration capacity of the liver².

In humans, the regeneration after liver resection happens in three months; in rats, in seven to ten days, so the experimental model to assess liver regeneration in rats is widely used and efficient ${ }^{3}$.

In the event of substantial loss of tissue, as in liver resection, there is cell division and intense tissue growth, promoting regeneration and changes in organ function. The energy and synthesis capacities of the newly formed liver mass is maintained. This process involves compensatory cell hyperplasia and hypertrophy, controlled and mediated by nutrients and growth factors ${ }^{2}$.

The use of diets enriched with glutamine showed benefits for surgical patients; thus, it is interesting to search for the relationship between liver regeneration and the use of supplemental glutamine. Probably the benefits of supplementation with dipeptides are due to their participation in urea genesis, gluconeogenesis and protein synthesis ${ }^{4}$.

The objective of this study was to evaluate liver regeneration after partial hepatectomy of approximately $60 \%$ in rats with and without supplementation of Lglutamine by assessing liver weight changes, laboratory parameters and histological study.

\section{METHODS}

The study was approved by the Ethics and Animal Experimentation of Maranhão State University under number 036/2012.

We used 36 adult, male, Wistar rats (Rattus norvegicus albinus, Rodentia mammalia) weighing between 195 and 330g. Four animals were housed per cage, were fed standard chow for the species, given water ad libitum and kept at a temperature of $23 \pm 2^{\circ} \mathrm{C}$, in a ventilated, noiseless environment, obeying a light/dark cycle of $12 \mathrm{~h}$. They were randomly assigned into two groups, 18 animals

1. Post-Graduation Program in Principles of Surgery, Medical Research Institute, Evangelical Faculty of Paraná / Evangelical University Hospital; 2. Department of Surgery Universidade Federal do Maranhão (UFMA), São Luís, MA, Brasil; 3. Faculdade Evangélica do Paraná/Hospital Universitário Evangélico de Curitiba, PR, Brasil. 
each. The first was defined as control and the second received $\mathrm{L}$ glutamine. Both were subdivided into three subgroups: death within $24 \mathrm{~h}, 72 \mathrm{~h}$ and seven days.

After pre-operative fasting for 6 hours and 15 minutes before surgery, we administered the first dose of L-glutamine ( $1 \mathrm{ml}$ per $100 \mathrm{~g}$ body weight) by gavage using a plastic tube. In the control group we added the same volume per $100 \mathrm{~g}$ body weight of $0.9 \%$ saline.

The animals were anesthetized after being weighed in a digital electronic scale. Anesthetic administration was intramuscular injection of $5 \%$ Ketamine $40 \mathrm{mg} / \mathrm{kg}$ and $2 \%$ xylazine $10 \mathrm{mg} / \mathrm{kg}$, applied to the posterior aspect of the thigh. Postoperative analgesia was made with application of dipyrone dose $0.1 \mathrm{ml}(500 \mathrm{mg} / \mathrm{ml}$ presentation).

Liver resection (60\%) was standardized according to the animal and liver weights; this was established after measuring of four animals out the study solely for this purpose, taking into account the rat/liver proportion. Six hours after surgery, the rats had free access to water and, after $12 \mathrm{~h}$, to the standard chow; The glutamine group, besides water and food, received $1 \mathrm{ml}$ of L-glutamine by gavage once daily at the same time, while the control group received $1 \mathrm{ml}$ of $0.9 \%$ sodium chloride.

In each subgroup we collected $4 \mathrm{ml}$ of blood for analysis of liver function (AST, ALT, GGT, bilirubin and albumin); then they were killed by anesthetic overdose. The liver was removed, exsanguinated, weighed and photographed. To calculate the rate of regeneration based on the weight, we used the formula of Kwon et al. ${ }^{5}$, ie: percentage of regeneration $=D / E \times 100(E=R / 0.7$, where $\mathrm{D}=$ liver weight per $100 \mathrm{~g}$ of animal weight on the day of sacrifice, $\mathrm{E}=$ estimated resected liver per $100 \mathrm{~g}$ before hepatectomy, and $R=$ weight of resected liver).

The specimens taken on the day of the experiment were immersed in 10\% formaldehyde and then sent to the pathology laboratory for histological sections and hematoxylin-eosin (HE) staining.

At first, we performed the Shapiro-Wilk normality test. Only the variables initial and final weight of the animal, final liver weight and ALT were normally distributed $(p>0.05)$. For the variables with normal distribution the Multivariate Analysis of Variance (MANOVA) test was applied with two factors (group and time) and then the Tukey test to make the post hoc comparisons over time. In the variables without normal distribution, the nonparametric Mann-Whitney test was used to assess the group effect and the Kruskal-Wallis test was applied for time. The significance level for rejecting the null hypothesis was $5 \%$, ie, a $p$ value $<0.05$ was considered statistically significant.

\section{RESULTS}

In the glutamine group, there was one animal death within the first 24 hours after the operation, before the time scheduled for its group, related to induction of anesthesia. Therefore, this animal was removed from the analysis.

When analyzing the initial weight of the rats and of the resected liver fragment, they were comparable interand intragroups $(p<0.05)$.

When evaluating the results of liver weight gain in relation to time of death, it was observed that there was a gain both in glutamine and control groups, as well as in both groups were analyzed separately, $(p<0.05)$; although not significant, weight gain was higher in the control group (Figure 1).

Upon assessment of liver function in relation to groups, we observed changes in GGT and albumin in both groups, with advantage for the glutamine group (Table 1).

Analysis of liver regeneration was performed using the number of mitoses (Table 2); we observed no statistically significant between groups, but when evaluated the time of death within each group (control and glutamine), there was an increase in mitosis at 72h (Figures 2 and 3).

The investigation mean rank revealed that liver regeneration was better in $72 \mathrm{~h}$ in the glutamine group compared with the control one (Figure 4).

\section{DISCUSSION}

Complex interactions are known to take place between nutrition, gut barrier function, immunoregulation and serious diseases, and today there is hope that certain forms of nutritional therapy may have benefits in specific diseases. Various formulations contain nutrients considered non-essential, but which in certain diseases become conditionally essential. Among these nutrients are: glutamine, arginine and omega-3 fatty acids ${ }^{6}$.

Glutamine has been shown as featuring numerous properties that favor the regeneration of many tissues, such as the liver. The study of these properties has become increasingly important ${ }^{7}$. Data from the metaanalysis by Novak et al. ${ }^{8}$ showed that glutamine supplementation may be associated with a reduction in

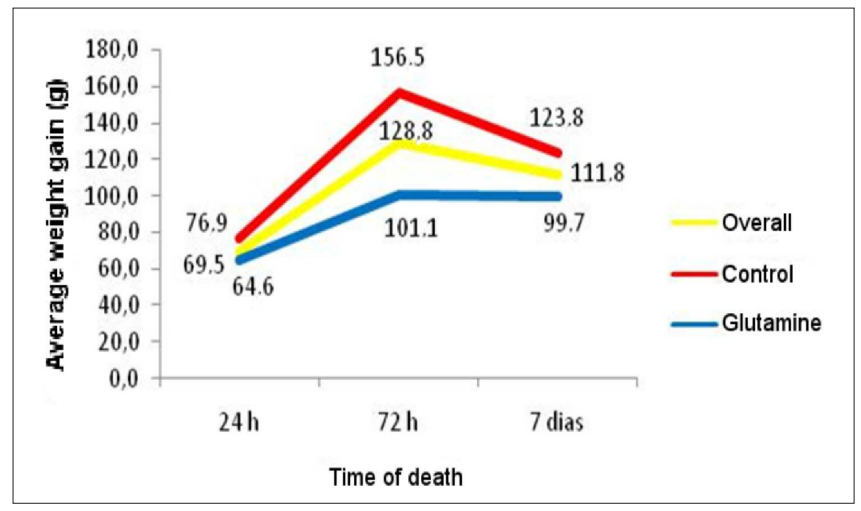

Figure 1 - Liver weight gain over time. 
Table 1 - Evaluation of liver function between groups.

\begin{tabular}{|c|c|c|c|c|}
\hline Variable & Group & $\mathrm{n}$ & Median & $p$ \\
\hline \multirow[t]{2}{*}{ AST } & Control & 18 & $243.5 \mathrm{a}$ & 0.064 \\
\hline & Glutamine & 17 & 318.0 a & \\
\hline \multirow[t]{2}{*}{ ALT } & Control & 18 & $164.5 \mathrm{a}$ & 0.448 \\
\hline & Glutamine & 17 & $202.0 \mathrm{a}$ & \\
\hline \multirow[t]{2}{*}{ Gama-GT } & Control & 18 & $5.0 \mathrm{a}$ & 0.015 \\
\hline & Glutamine & 17 & $2.5 \mathrm{~b}$ & \\
\hline \multirow[t]{2}{*}{ Total bilirubin } & Control & 18 & $0.90 \mathrm{a}$ & 0.722 \\
\hline & Glutamine & 17 & $0.90 \mathrm{a}$ & \\
\hline \multirow[t]{2}{*}{ Indirect bilirubin } & Control & 18 & $0.30 \mathrm{a}$ & 0.242 \\
\hline & Glutamine & 17 & $0.30 \mathrm{a}$ & \\
\hline \multirow[t]{2}{*}{ Direct bilrrubin } & Control & 18 & $0.60 \mathrm{a}$ & 0.541 \\
\hline & Glutamine & 17 & $0.60 \mathrm{a}$ & \\
\hline \multirow[t]{2}{*}{ Albumin } & Control & 18 & $0.90 \mathrm{~b}$ & 0.027 \\
\hline & Glutamine & 17 & $1.00 \mathrm{a}$ & \\
\hline
\end{tabular}

$a, b$ (different letters) means $p<0.05$ in relation to time.

Table 2 - $\quad$ Analysis of mitoses.

\begin{tabular}{llrlr}
\hline Group & Time & N & Median & p \\
\hline Control & & 18 & $4.0 \mathrm{~A}$ & 0.056 \\
& $24 \mathrm{~h}$ & 6 & $10.5 \mathrm{a}$ & 0.088 \\
Glutamine & $72 \mathrm{~h}$ & 6 & $2.0 \mathrm{a}$ & \\
& 7 days & 6 & $1.0 \mathrm{~A}$ & 0.003 \\
& $24 \mathrm{~h}$ & 17 & $1.0 \mathrm{~b}$ & $6.0 \mathrm{a}$ \\
\\
\hline
\end{tabular}

$A=p>0.05$ for group .

$a, b$ (different letters) means $p<0.05$ for time within group.

infectious complications, oxidative stress and mortality rates in critically ill patients.

Liver regeneration evaluated by the Kwon formula in the work of Gama Filho et al. ${ }^{9}$ was significant in the control group as in the experiment one (using

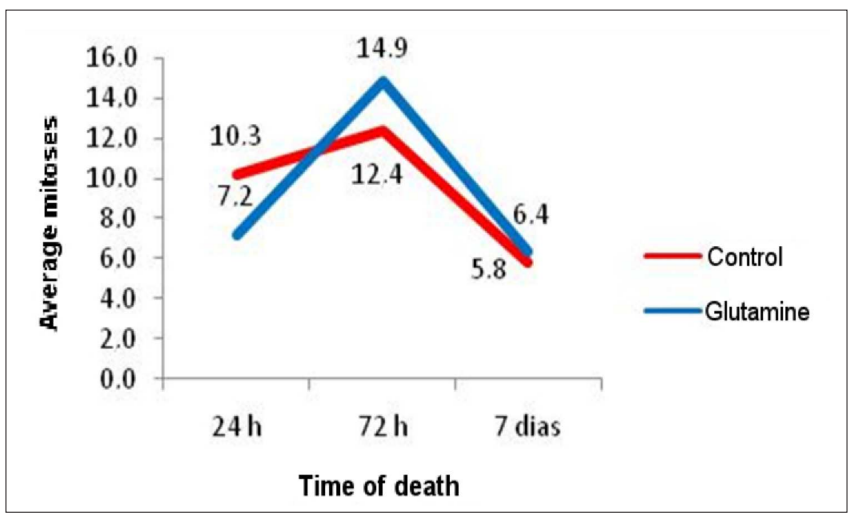

Figure 2 - Number of mitoses per filed.
Tacrolimus) in the first 24 hours and on the seventh posthepatectomy day. When the values were compared within each group there was an increase in both, more pronounced in the study group. A study similar to that, also using the Kwon formula to calculate the rate of liver regeneration in rats, revealed that the remaining liver had higher volume in both groups (control/experiment) both within 24 and seven days, but without statistical significance. The experiment group received glutamine supplementation at a dose 50ìg/day orally?.

The results of this study regarding the rate of liver regeneration by the Kwon formula show statistically significant remnant liver weight gain in both groups (control/ glutamine), when compared to the time of the experiment, however more significant in the control group. When comparing both groups, the difference was significant only at $72 \mathrm{~h}$, better in the control group.

In this study, when laboratory tests were evaluated, there was increase in the amounts of albumin in the glutamine group compared with the control 


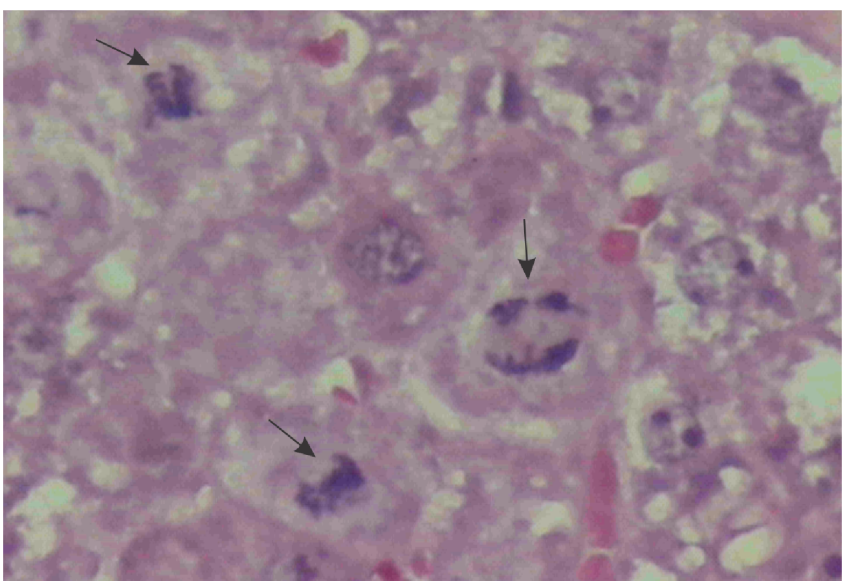

Figure 3 - Photomicrograph of liver section of the Glutamine group stained by HE - presence of mitosis (arrows).

$(p=0.027)$. The levels of gamma-GT increased in the control group compared with the glutamine $(p=0.015)$. Various biochemical tests can be used to evaluate hepatic profile, such as dosing alanine aminotransferase (ALT), aspartate aminotransferase (AST) AST/ALT ratio, gama-glutamyl transpeptidase (GGT), alkaline phosphatase, prothrombin time, bilirubin and albumin. Nevertheless, severe liver disease may present with normal levels of liver enzymes, or cause alterations of 1.5 to 3 times above the reference levels ${ }^{10}$. In an experimental study in rats supplemented with immunomodulating diet, Torres et al. ${ }^{11}$ observed increased amounts of albumin in the group supplemented with immunonutrition.

The progressive enlargement of the liver is due to two peaks of mitosis, normally encountered during the regeneration process. The peak first occurs in the first 24 hours after hepatectomy and is related exclusively to hepatocytes ${ }^{12}$. The second takes place with the participation of non-parenchymal cells and, in rats, occurs in 72 hours, being evident in liver resections greater than $50 \%{ }^{13}$.

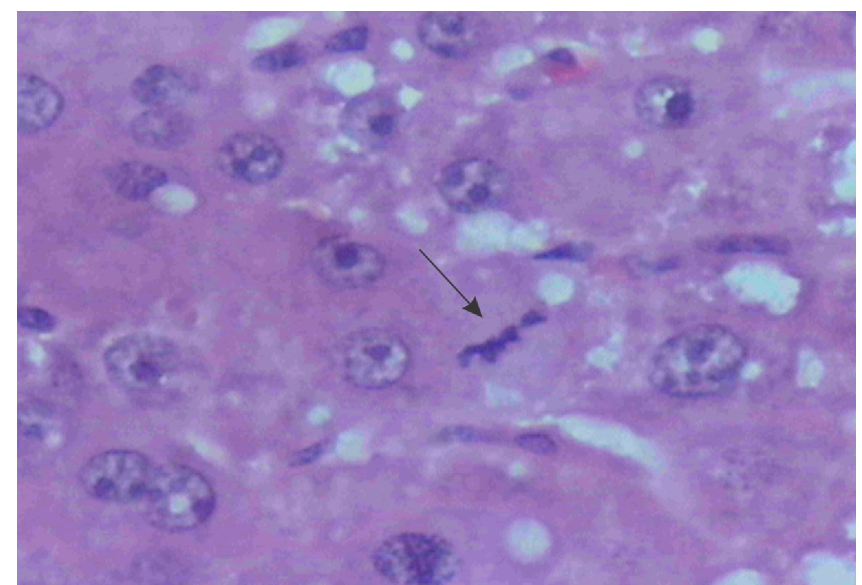

Figura 4 - $\quad$ Photomicrograph of liver section of the Control group stained by HE - Presence of mitosis (arrow).

Glutamine supplementation to rats leads to increased replication of hepatocytes with $24 \mathrm{~h}$, being beneficial to liver regeneration ${ }^{7}$. In their study testing the effect of tacrolimus on liver regeneration, Gama Filho et al. ${ }^{9}$ found inter- and intragroup statistical difference in periods of 24 hours and seven days, with a gradual increase in the mitotic index, therefore concluding that the more time under the action of Tacrolimus, the greater the positive effect on liver regeneration, which does not corroborate the results of this work, where we found a greater number of intragroup mitosis (glutamine group) only at 72 hours of the experiment $(p=0.003)$. Among groups there was a trend towards statistical significance $(p=0.056)$.

Tarlá et al. ${ }^{1}$, highlighted that after $72 \mathrm{~h}$ the histological appearance of the liver tissue changes dramatically compared with normal tissue, with proliferation of hepatocytes in non-vascularized clusters and yet with no synthesis of new extracellular matrix.

Supplementation of L-glutamine to the diet of rats was beneficial for liver regeneration.

\title{
R E S U M O
}

\begin{abstract}
Objetivo: Avaliar a regeneração hepática em ratos submetidos à hepatectomia de 60\% com e sem suplementação de L-glutamina através de alteração ponderal do fígado, parâmetros laboratoriais e estudo histológico. Métodos: Foram usados 36 ratos machos, distribuídos em dois grupos: grupo controle e grupo glutamina. Cada um foi subdividido em mais três subgrupos com óbito em $24 \mathrm{~h}$, $72 \mathrm{~h}$ e sete dias. O grupo glutamina recebeu água e dieta padrão suplementada com L-glutamina e o controle solução fisiológica a 0,9\%. Em todos os subgrupos foi feita análise da regeneração hepática através da fórmula de Kwon, estudo da função hepática (AST, ALT, gama GT, bilirrubina total, bilirrubina indireta e indireta e albumina) e análise de mitose celular pela coloração de Hematoxilina - Eosina. Resultados: Nos dois grupos houve regeneração hepática pelo ganho ponderal. Gama GT aumentou significativamente no grupo controle $(p<0,05)$ já albumina aumentou no da glutamina. Os demais indicadores da função hepática não apresentaram diferenças significantes. A análise histológica em $72 \mathrm{~h}$ mostrou maior número de mitoses no grupo glutamina, não havendo diferença nos demais subgrupos. Conclusão: A suplementação de L-glutamina à dieta é benéfica para a regeneração hepática.
\end{abstract}

Descritores: Avaliação. Hepatectomia. Regeneração hepática. Dieta. Glutamina. 


\section{REFERENCES}

1. Tarlá MR, Ramalho F, Ramalho LNZ, Castro e Silva T, Brandão DF Ferreira J, et al. Cellular aspects of liver regeneration. Acta Cir Bras. 2006;21(Suppl 1):63-6.

2. Kurokawa T, An J, Tsunekawa K, Shimomura Y, Kazama S Ishikawa $N$, et al. Effect of L-arginine supplement on liver regeneration after partial hepatectomy in rats. World J Surg Oncol. 2012:10:99

3. Torres OJM, Arraes LRG, Ferreira EDZ, Coutinho IHILS, Dominic AJ. Hepatectomia central. ABCD arq bras cir dig. 2005;18(1):30-2.

4. Naka S, Saito H, Hashiguchi $Y$, Lin MT, Furukawa S, Inaba T, et al. Alanyl-glutamine-supplemented total parenteral nutrition improves survival and protein metabolism in rat protracted bacterial peritonitis model. JPEN J Parenter Enteral Nutr. 1996;20(6):41723.

5. Kwon AH, Uetsuji S, Yamamura M, Hioki K, Yamamoto M. Effect of administration of fibronectin or aprotinin on liver regeneration after experimental hepatectomy. Ann Surg. 1990;211(3):295-300.

6. Okawa L. Influência da suplementação enteral pré-operatória com dieta enriquecida com arginina, ácidos graxos ômega-3, nucleotídeos e oligoelementos na cicatrização de anastomoses colônias em ratos: estudos tensiométrico e da densitometria do colágeno [dissertação]. Curitiba: Universidade Federal do Paraná, Faculdade de Medicina; 2009.

7. Biondo-Simões MLP, Matias JEF, Martone D, Barbosa RF, Ogawa GH. Inûuência da glutamina na regeneração hepática. Rev med (São Paulo). 2007:86(4):219-23.

8. Novak F, Heyland DK, Avenell A, Drover JW, Su X. Glutamine supplementation in serius illness: a systematic review of the evidence. Crit Care Med. 2002;30(9):2022-9
9. Gama Filho O, Toderke EL, Baretta GAP, Sakamoto DG, Agulham MA, Tambara EM, et al. Imunossupressão com tacrolimus favorece a regeneração hepática induzida por hepatectomia extensa em ratos. $A B C D$ arq bras cir dig. 2010;23(2):74-80.

10. Zamin Jr I, Matos AA, Perin C, Ramos GZ. A importância do índice AST/ALT no diagnóstico da esteatohepatite não-alccólica. Arq Gastroenterol. 2002;39(1):22-6.

11. Torres OJM, Campos ACL, Malafaia O, Melo TCM, Marques SG Dietz UA. Translocação bacteriana: efeito de dieta imunoestimuladora em ratos com oclusão intestinal. Rev Col Bras Cir. 1999:26(1):1-6

12. Fausto N, Riehle KJ. Mechanisms of liver regeneration and their clinical implications. J Hepatobiliary Pancreat Surg. 2005;12(3):1819.

13. Koniaris LG, Mckillop IH, Schwartz SI, Zimmers TA. Liver regeneration. J Am Coll Surg. 2003;197(4):634-59.

Received on 03/01/2013

Accepted for publication 08/02/2013

Conflict of interest: none.

Source of funding: none.

How to cite this article:

Magalhães CR, Malafaia O, Torres OJM, Moreira LB, Tefill SCSG, Pinheiro MR, Harada BA. Avaliação da regeneração hepática com dieta suplementada com L-Glutamina: estudo experimental em ratos. Rev Col Bras Cir. [periódico na Internet] 2014;41(2). Disponível em URL: http://www.scielo.br/rcbc

Address for correspondence:

Cibelle Ribeiro Magalhães

E-mail: cibelle.magalhaes@hospitalsaodomingos.com.br 